\title{
Continuing professional development (CPD) for junior high school mathematics teachers: An evaluation study
}

\author{
${ }^{* 1}$ Pika Merliza; ${ }^{2}$ Heri Retnawati \\ ${ }^{1,2}$ Department of Mathematics Education, Universitas Negeri Yogyakarta \\ Jl. Colombo No. 1, Depok, Sleman 55281, Yogyakarta, Indonesia \\ ${ }^{*}$ Corresponding Author. E-mail: pikamerlizasoemali@gmail.com \\ Submitted: 06 March 2018 | Revised: 01 August 2018 | Accepted: 15 November 2018
}

\begin{abstract}
Responding to the importance of conducting evaluation on continuing professional development program for teachers, this study is aimed at describing the implementation and difficulty of Continuing Professional Development (CPD) of mathematics teachers of Junior High School (JHS) in Bandar Lampung, Indonesia. This research used a descriptive approach employing a quantitative-qualitative method with sequential explanatory strategy. The population of the research was 181 junior high school mathematics teachers who have already become civil servants. The samples were 63 teachers for quantitative research selected using stratified random sampling and proportional random sampling technique, while eight teachers for qualitative research were selected using purposive sampling technique. These eight teachers were selected because they were the only teachers handling the CPD program. The data were collected through a test, questionnaires, checklist sheet, study document, and interview. Data analysis was conducted using categorized performance trends, divided into five groups: Very Good/Difficult, Good/Difficult, Fair, Poor/Easy, and Very Poor/Very Easy. The data were analyzed using descriptive technique; the quantitative study analysis was performed by mean and standard deviation, whereas, the qualitative data analysis was obtained by data reduction, data display, and conclusion technique. The research results show that the majority of teachers' CPD implementation is very poor, meanwhile, the difficulty of the engagement of CPD is categorized as fairly difficult.
\end{abstract}

Keywords: junior high school mathematics teachers, continuing professional development (CPD), teaching experience

\section{Introduction}

As a developing country, Indonesia aspires to improve becoming a developed country which is independent, unified, sovereign, just, and prosperous (Preamble of the 1945 Constitution of the Republic of Indonesia). Various attempts are made to embody the ideals of the nation, one of which through the efforts of alleviation of poverty and unemployment, which became conspicuous case of developing countries. The high number of poverty and unemployment will impact badly on various aspects of life, such as increasing numbers of violence, theft, robbery, depression, political instability, and many others.
According to Yacoub (2012, p. 178), if a community has job and earnings (instead of unemployment), and then the earnings are expected to meet the necessities of life, so it is stated that they are not poor. It can be inferred that by the low unemployment number, then the number of poverty is also low.

One of the factors contributing to the high number of unemployment is the low quality of human resources who are able to compete in both national and global scope. Nationally and globally competitive human resources provide opportunities to get a job to fulfill their life necessities and decrease the level of poverty of the nation. The low quality of the nation's human resources is a product of the poor quality of education. This is due 
to the fact that education has a major influence for various aspects of sustainable life development and the supporting factors contributing to the sustainability and peace, giving a direct influence to decrease poverty, and also promoting health, gender, and sustainable environment (UNESCO, 2014, p. 25). The importance of the influence of education to human life becomes one of the factors underlying UNESCO to continue stating the idea of lifelong learning which is started since 1972 (Tuijnman \& Boström, 2002, p. 95).

The enhancement of abilities, skills, and attitudes determines the quality of human resources of a nation. Thus, it is the responsibility of every individual to become a lifelong learner, to learning developing themselves, to continue and enhance the competence and expertise along with the development of science and technology. This responsibility is valid to everyone in profesion, including teachers. Teachers are demanded to conduct professional development throughout their career related to the role and responsibility (Gray, 2005, p. 5).

Based on a research related to the implementation of CPD for teachers, Nuraeni and Retnawati (2016, pp. 137-138) reveal that the effectiveness of subject-matter teachers forum (MGMP) still belongs to the low category. Nuraeni and Retnawati (2016) suggest that the activities of the MGMP - that have been established in each regency and province allegedly - have not functioned optimally to facilitate the mathematics teachers to develop themselves.

Furthermore, in regard to the performance of post-certification teachers, the facts show that not all certified teachers in Indonesia have good competences and performances (World Bank in Jalal et al., 2009, p. 7). This is in line with a research conducted by Abubakar (2015, p. 116) about the impact of certification on Madrasah Aliyah teachers' competence in Kendari, South East Sulawesi, Indonesia, which states that teachers' certification has not had a positive impact on their competence improvement, either in their subject area or educational unit.

It is proven by the findings of a research of Kardiyem (2013, p. 17) that the overall performance of certified teachers in senior vocational schools in Grobogan Regency, East Java, Indonesia is in 'not good' category. Various obstacles are faced by the teachers, including low motivation achievement, limited time, lack of knowledge, and perceptions on the government regulations. In addition, the teachers' level of competence and skills before and after the certification is still the same. The teachers are less trying to improve their competence and tend to perform the same as before getting the certificate. As reported by Nuraeni and Retnawati (2016, p. 130) in their research on teacher performance in professional development in $\mathrm{Wo}-$ nosobo Regency, the teachers are still categorized as very poor in professional development, and certified teachers have less awareness in their professional development. Further, Fahmi, Maulana, and Yusuf (2011, p. 15) emphasize that teacher certification was expected to improve teachers' quality, however, in fact, it does not contribute positively to the improvement of the students' learning process.

This condition is contradictory to the Law No. 14 Year 2005 of Republic of Indonesia about Teachers and Lecturers, which states that in performing professional duties, teachers are obligated to improve and develop academic qualifications and competencies in a sustainable manner in line with the development of science and technology. All teachers must have professionalism in their profession; teachers must be mastering the competencies needed to achieve educational aim. Competence is an important component to support the performance of teachers in performing their duties and roles.

According to Hamilton-Ekeke (2013, p. 15), teacher competence is the ability of a teacher to help learners to reach higher levels of learning. Competence requires teachers to carry out professional responsibilities, hence the effectiveness of the implementation of teacher role as a learning agent depends on the teacher's level of competence. The teacher's level of competence is related to the professional and pedagogical knowledge. In Indonesia, teachers' professional competency standard consists of professional, pedagogic, 
social, and personality competence (Regulation of the Minister of National Education No. 19 of 2005 on National Education Standard). The four competencies must be mastered by all of professional teachers in Indonesia, including mathematics teachers.

Mathematics is one of the important subjects that equips learners in facing a fullycompetitive life. Alnoor and Yuanxiang (2000, p. 1) explain that mathematics is a necessary tool in the field of science and technology, since it aims not only to teach arithmetic, but also provides opportunities for learners to become scientists - exploring concepts related to everyday life. The purpose of mathematics education which requires logical, analytical, systematic, critical, and creative thinking as well as cooperative ability (Regulation of the Minister of Education and Culture No. 20 of 2016 on the competence standard of primary and secondary education graduates) are very useful in preparing highly competitive generation. It means that in order to reach a high quality mathematics learning, the competence of qualified teachers is required. It is essential for teachers to continue improving their competence to support their carriers. This is not only a demand for in-service mathematics teachers, but also for pre-service teachers.

According to the data of World Bank (2010, p. 18), 'Mathematics teachers have scored poorly on competency exams, raising concerns about the quality of their instruction'. Further results of teacher competency test indicate a significant impact on the learning practices seen from the learners' achievement (Ünal, Demir, \& Kiliç, 2011, p. 3252). For example, data of National Examination (or Ujian Nasional - UN) result of junior high school in Bandar Lampung in the academic year of 2015/2016 released by National Education Standards Board (Badan Standar Nasional Pendidikan, 2015) show that the average score of mathematics is 53.99. This score is lower than other subjects such as Indonesian, English, and science which are 71.84, 64.28, and 63.66. This is assumed that mathematics' low average score is due to its non-routine patterns of questions with increasing challenges provided for the students which are not able to solve only through calculation, but also require higher order thinking skill, involvement of reasoning, analyzing, synthesizing, and evaluating. By this situation, the tasks and roles of mathematics teacher of junior high school are great in establishing the learning situations. Teachers are the determinant factor of students' learning experiences in the classroom, who prepare students to have higher order thinking skill (UNICEF, 2007, p. 93).

Furthermore, teachers are the central point to significantly improve their own competences. Teachers' knowledge and skills are the factors that influence the success of classroom learning. In the mid of rapid technological advances, as a professional, and due to the demand for high standard of education, teachers must continue learning (in-services learning) in order to improve their competence.

Continuing Professional Development (CPD) is a continuing learning for teachers who are the main vehicle in the effort to bring the desired changes related to the success of the learners (Ministry of National Education of Republic of Indonesia, 2010, p. 9). In the case of teaching, development which can be made is in-service training. The content of CPD for mathematics teacher is believed to revitalize the teacher's skills in designing the teaching and learning process, increasing enthusiasm on the instruction, and also help to maintain their scientific knowledge Joubert, Back, De Geest, Hirst, \& Sutherland, 2010, p. 1765).

The concept of CPD for teachers has been implemented in many various countries around the world. In Finland, the concept of CPD for teacher is based on the idea of 'longlife learning'. The government has adopted the concept of CPD since the education of prospective teachers at university level. The implementation of CPD agenda for teachers during 7 days in a year should be involved in inter-school teacher training. In addition, as another form of CPD implementation for teachers, the Finnish government requires all teachers to pursue higher education to attain at least a master degree as a minimum standard of teachers' education level (Layne, 2016, p. 9). In the UK, the types of CPD include: 
(1) workshops held at school or outside the school, (2) certified courses, (3) courses held at the university, (4) teacher collaboration activities, (5) conferences, (6) guiding, training, or observing fellow teachers in teaching (lesson study), (7) joining committees, (8) teacher learning communities, and (9) self-learning (Opfer \& Pedder, 2010, p. 241).

In Indonesia, CPD for teachers has been set forth in the Regulation of the Minister for the State Apparatus Empowerment and Bureaucracy Reform No. 16 of 2009, enforced in 2013, that teacher who has a certificate of educator is required to implement CPD with the calculated credit number. The credit number is needed by teachers to achieve higher degree which is automatically influential to their salary. CPD in Indonesia consists of: (1) subsection of self-development, (2) scientific publications, and (3) innovative works.

CPD activities provide benefits for teachers to improve their knowledge, skills, and competencies according to their professional standards. Adey, et al. (Wermke, 2011, p. 669) state that there are three important facts which become the basis of CPD for teachers: (1) CPD activities improve teachers' new understanding of learning and their belief; (2) CPD for teachers is influential to the classroom instructional practice in the form of feedback on CPD activities; (3) CPD for teachers is based on intuitive knowledge that influences the teachers' attitude intuition, one of which is influenced through training process. Thus, CPD can provide benefits for teachers' beliefs as well as classroom instructional practices.

In addition, Desimone (2009, pp. 183 184) states that the benefits of professional development for teachers are; (1) CPD can improve the teachers' knowledge and skills and/or change their attitudes and beliefs; (2) knowledge, skills, attitudes, and beliefs will be influential to improve the content knowledge that gives impact on pedagogical knowledge in the teaching practice; (3) CPD can cause changes in the way of teaching that has a positive impact towards the improvement of the learners' learning outcomes. However, based on the research results on CPD activities in some areas of Indonesia, the implementation of CPD is still not encouraging. Based on the results of Nuraeni and Retnawati (2016, pp. 137-138), the professional development of mathematics teachers of vocational senior high school in Wonosobo Regency is categorized in 'poor' category.

This situation is in line with the finding of Kartowagiran (2011, p. 463) stating that post-certification teachers' performance in professional development is still unsatisfying. Moreover, based on the results of a research conducted by Noorjannah (2015, p. 107), there is fraud conducted by teachers in the CPD, especially in the paper writing; $70 \%$ of the teachers employ writing services, action research, promotion, or conduct certain activities such as certification. According to the research findings by Aina, Bambang, Retni, Afreni, and Sadikin (2015, p. 31), the number of scientific papers published by teachers is low due to their difficulties in writing. The difficulties are related to the teaching hours, writing ethic and techniques, and unaccustomed experience of expressing ideas in a writing project.

According to Supriyanto (2015, p. 111), scientific writing in the CPD produced by teachers is basically not conducted periodically, and the policy of writing scientific paper for promotion is not responded positively. Furthermore, based on the research findings of Wibowo and Jailani (2014), the CPD of mathematics teachers of junior high school in Wonosobo based on its understanding, implementation, and difficulties are categorized in 'medium', 'low', and 'very low' categories. These categorizations may be caused by the difficulties faced by teachers in the implementation of CPD. Qablan, Mansour, Alshamrani, and Aldahmash (2015, p. 627) mention the obstacles in implementing CPD, including excessive workload, teaching hours, location of the activities, time of teaching, personal circumstances, funding, and the activities.

Furthermore, based on the data gained from interviews to mathematics teacher of junior high school in Bandar Lampung regarding the CPD activities, it is found that teachers do not focus to do their duty to teach mathematics in the class. It means that 
teachers have tried to conduct CPD but they find various difficulties. Thus, this research aims to find out the implementation of CPD and the difficulties faced by mathematics teachers of junior high school in Bandar Lampung in conducting CPD.

\section{Method}

This research used descriptive approach employing quantitative-qualitative method (or mixed methods). The study was conducted at junior high schools in Bandar Lampung, Indonesia. Data collection was conducted from February to March 2017, through direct meeting of the researchers with respondents at their respective schools and mathematics subject-teachers forum (or Musyawarah Guru Mata Pelajaran - MGMP) for junior high school (JHS) teachers in Bandar Lampung.

The population in this research was 181 mathematics teachers of junior high schools in Bandar Lampung in the academic year of 2016/2017. Samples were identified using stratified random sampling procedure based on the teachers' teaching experiences, then subsequently selected through proportional random sampling technique. The samples were 63 mathematics teachers, whereas for qualitative research, eight respondents were chosen using purposive sampling technique.

\section{Research Procedure}

The research used mixed methods research design in the form of sequential explanatory design, in which the process of data collection were not done at the same time. The researchers collected and analyzed the quantitative data firstly, then the analyzed data were used as the basis for collecting and analyzing the qualitative data. The flow is presented in Figure 1.

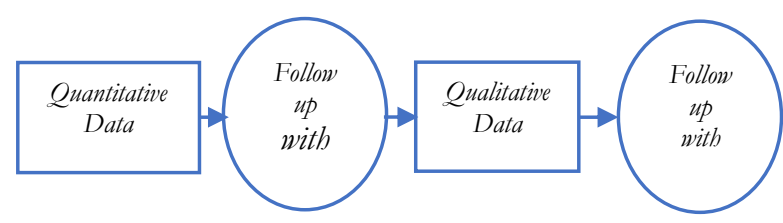

Figure 1. Research setting of sequential explanatory design (Creswell \& Clark, 2011, p.

68)
The results of analysis from both studies were combined and compared, so that it was known which qualitative data were appropriate, expanded, or even aborted the results of quantitative data. Furthermore, the results of the both data were presented in a table to draw conclusions.

Data, Instruments, and Data Collection Techniques

The instruments which were employed in this study consist of checklist and document study which were used to measure the implementation of CPD for teachers, consisting of: (1) 27 items of CPD implementation on self-development sub-section; (2) 23 items of CPD implementation on scientific publication sub-section; and (3) 21 items of CPD implementation on innovative works sub-section. Document study was developed from the checklist to check the physical evidence related to the involvement of CPD activities in each aspect.

Furthermore, the instruments were in the form of 15 items of questionnaire about the difficulties aspect with a semantic differential scoring scale with the intervals of 1-7. The items were equipped with very easy to very difficult choices and were completed by 15 items of open-ended questions related to the efforts in overcoming the difficulties. In addition, an instrument in the form of an interview guidance was used to measure all aspects of CPD. The validity of the instruments was in the form of content validity: face and logical validity, and was done by two expert judgments. The reliability of the instrument difficulty was 0.964 and the SEM was 15.263, which means that it was in a very good category of reliability.

\section{Data Analysis Technique}

The quantitative data analysis was presented in the table based on the tendency of the respondents' answer on one of the criteria in each sub-variable. In categorizing the percentage of quantitative descriptive analysis, the researchers employed the categorization adapted from Widoyoko (2013, p. 238), which is presented in Table 1. 
Table 1. Assessment categories

\begin{tabular}{l|c}
\hline \multicolumn{1}{c|}{ Formulas } & Category \\
\hline$X>M i+1,8 S b i$ & Very Good \\
$M i+0,6 S B i<X \leq M i+1,8 S B i$ & Good \\
$M i-0,6 S B i<X \leq M i+0,6 S B i$ & Fair \\
$M i-1,8 S B i<X \leq M i-0,6 S b i$ & Poor \\
$X \leq(M i-1,8 S B i)$ & Very Poor \\
\hline
\end{tabular}

Note:

$M i=$ ideal mean score

$S B i=$ ideal standard deviation

$X=$ score of the respondents or actual score

Qualitative Descriptive Analysis Technique

The qualitative data which were obtained through interview and document study were analyzed by interactive model, and then the result of the data analysis was processed through the following flow: data reduction, data display, conclusion drawing, and verification (Miles, Huberman, \& Saldaña, 2014, pp. 12-13). The data analysis techniques are presented in Figure 2.

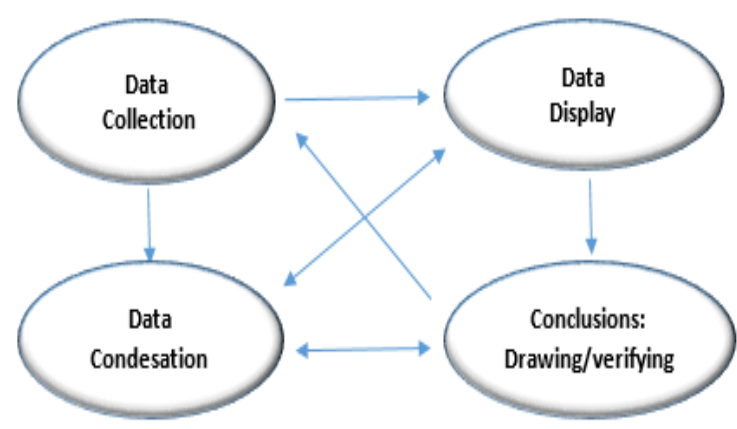

Figure 2. Interactive model analysis scheme

At the data reduction stage, simplifying the activities and selecting the key points were performed to create a core summary without changing the message. Furthermore, in the presentation stage, the data processed were briefly displayed on a table to make it easy to understand the unit related to the steps of the research. The last stage is the conclusion stage, in which the researchers collected the data in order to draw conclusion based on the tendency of the same or similar data categorization. This conclusion stage is temporary, so that the researchers need to verify the conclusion which was drawn with the data categorization and the quantitative data to make it more credible.

\section{Findings and Discussion}

Findings

Implementation of CPD to Mathematics Teachers of Junior High School

Based on the results of CPD checklist sheet of mathematics teachers which includes self-development, scientific publication, and innovative works aspects, the implementation of CPD activities has the actual mean score (X) of 48.42 (very poor category), the ideal score (Mi) of 162.5, and the ideal standard deviation of 54.17 with maximum score 325 and minimum score of 65 , as presented in Table 2.

Table 2. Score of CPD implementation to mathematics teacher of junior high school

\begin{tabular}{lcc}
\hline \multicolumn{1}{c}{ Category } & Total & Percentage \\
\hline Very Good & 0 & $0 \%$ \\
Good & 0 & $0 \%$ \\
Fairly Good & 0 & $0 \%$ \\
Less Good & 3 & $5 \%$ \\
Very Poor & 60 & $95 \%$ \\
Total & $\mathbf{6 3}$ & $\mathbf{1 0 0 \%}$ \\
\hline
\end{tabular}

Table 2 shows that the performance of 95\% of junior high school mathematics teachers in Bandar Lampung in implementing CPD activities is in 'very poor' category, meaning that the majority of the teachers are still less involved in the CPD activities, either in person or inside the mathematics teachers' learning community/institutions, both in formal and non-formal learning.

Furthermore, the overall results of the implementation of CPD activities are obtained based on the details of each aspect. In the aspects of self-development, the actual score $(\mathrm{X})$ is 33.32 (very poor category), the ideal score (Mi) is 81, the ideal standard deviation is 18.00 with the maximum score of 135 , and the minimum score of 27 .

In addition, the result of CPD implementation of junior high school mathematics teachers in Bandar Lampung seen from scientific publication aspect, the actual score $(\mathrm{X})$ is 6.93 (very poor category). The mean ideal score is 69 , the ideal standard deviation is 15.33 with the maximum score of 115 and the minimum score of 23 . Besides, in innovative 
works aspect, the actual score $(\mathrm{X})$ is 8.68 (very poor category), the ideal score (Mi) is 45 , the ideal standard deviation is 10.00 with the maximum score of 75 and the minimum score of 15 . The detail score of each aspect is presented in Table 3.

\section{Difficulties of CPD Implementaion to JHS Mathe- matics Teachers}

Based on the teachers' responses to the questionnaire, the actual score $(\mathrm{X})$ is 505.39 (quite difficult category), the ideal score (Mi) is 452 , the ideal standard deviation is 113.00 with maximum score of 113 and minimum score of 452. To make it clear, the difficulty criteria are presented in Table 4.

Based on Table 4, $70 \%$ of JHS mathematics teachers have difficulties in conducting CPD activities, while the $30 \%$ have no difficulties to be involved in CPD. It means that more than half respondents have difficulties in actively participating in the activities on all aspects. In more detail, $8 \%$ of the teachers are in difficult category, $62 \%$ of teachers are in the quite difficult category, and 30\% of teachers have no difficulties to conduct CPD. The overall data of the difficulties category for the details of each CPD activity are presented in Table 5.

Based on Table 5 , less than $30 \%$ of the teachers stated that they have no difficulties in engaging each aspect of CPD. In the aspect of self-development, most of the respondents $(30 \%)$ are included in the fair category, whereas in the aspect of scientific publication, they mostly are in the difficult category $(52 \%)$, and in the aspect of innovative works, they are in the very difficult category $(40 \%)$. Meanwhile, the percentage comparison of the number of teachers who have difficulties in conducting CPD is presented in Figure 3.

Table 3. CPD implementation score of self-development, scientific publications, and innovative works

\begin{tabular}{lcccccc}
\hline \multirow{2}{*}{ Category } & \multicolumn{2}{c}{ Self-Development } & \multicolumn{2}{c}{ Scientific Publications } & \multicolumn{2}{c}{ Innovative Works } \\
\cline { 2 - 7 } & Total & $\mathbf{( \% )}$ & Total & $\mathbf{( \% )}$ & Total & $\mathbf{( \% )}$ \\
\hline Very Good & 0 & $0 \%$ & 0 & $0 \%$ & 0 & $0 \%$ \\
Good & 0 & $0 \%$ & 0 & $0 \%$ & 0 & $0 \%$ \\
Fair & 0 & $0 \%$ & 0 & $0 \%$ & 0 & $0 \%$ \\
Less Good & 2 & $3 \%$ & 0 & $0 \%$ & 0 & $0 \%$ \\
Very Poor & 61 & $97 \%$ & 63 & $100 \%$ & 63 & $100 \%$ \\
$\quad$ Total & $\mathbf{6 3}$ & $\mathbf{1 0 0} \%$ & $\mathbf{6 3}$ & $\mathbf{1 0 0} \%$ & $\mathbf{6 3}$ & $\mathbf{1 0 0 \%}$ \\
\hline
\end{tabular}

Table 4. Score of CPD difficulties of mathematics teachers

\begin{tabular}{lcc}
\hline \multicolumn{1}{c}{ Category } & Total & Percentage \\
\hline Very Difficult & 0 & $0 \%$ \\
Difficult & 5 & $8 \%$ \\
Fair & 39 & $62 \%$ \\
Easy & 19 & $30 \%$ \\
Very Easy & 0 & $0 \%$ \\
$\quad$ Total & $\mathbf{6 3}$ & $\mathbf{1 0 0} \%$ \\
\hline
\end{tabular}

Table 5. Score of difficulties of CPD implementation on self-development, scientific publishing and innovative works

\begin{tabular}{lcccccc}
\hline \multirow{2}{*}{ Category } & \multicolumn{2}{c}{ Self-Development } & \multicolumn{2}{c}{ Scientific Publications } & \multicolumn{2}{c}{ Innovative Works } \\
\cline { 2 - 7 } & Total & $\mathbf{( \% )}$ & Total & $\mathbf{( \% )}$ & Total & $\mathbf{( \% )}$ \\
\hline Very Difficult & 8 & $13 \%$ & 0 & $0 \%$ & 25 & $40 \%$ \\
Difficult & 8 & $13 \%$ & 33 & $52 \%$ & 21 & $33 \%$ \\
Fair & 34 & $54 \%$ & 27 & $43 \%$ & 15 & $24 \%$ \\
Easy & 13 & $20 \%$ & 3 & $5 \%$ & 2 & $3 \%$ \\
Very Easy & 0 & $0 \%$ & 0 & $0 \%$ & 0 & $0 \%$ \\
$\quad$ Total & $\mathbf{6 3}$ & $\mathbf{1 0 0 \%}$ & $\mathbf{6 3}$ & $\mathbf{1 0 0 \%}$ & $\mathbf{6 3}$ & $\mathbf{1 0 0 \%}$ \\
\hline
\end{tabular}




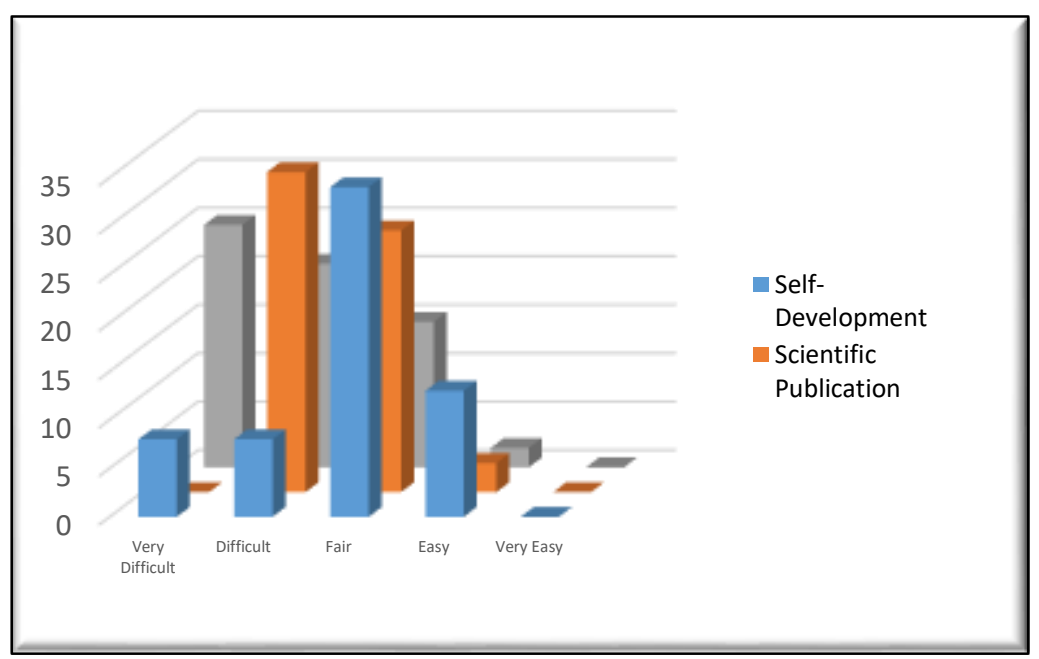

Figure 3. Diagram of comparison of questionnaire results of CPD implementation to mathematics teachers in Bandar Lampung

Based on Figure 3, the mean score of the difficulty of CPD implementation to the majority of mathematics teachers in Bandar Lampung on doing scientific publication is in difficult category. Besides, the difficulty faced by mathematics teachers in doing self-development is in fair category.

In each aspect of activities, JHS mathematics teachers in Bandar Lampung obtained information on self-development, namely (1) teachers' participation in the functional training and collective activities is related to the schedule and location of the activities and also the limitation of the participants; the difficulties to attend a master program are related to information, family permission, and funding; (2) difficulties in conducting action research (publications); it is found that some teachers have difficulties in identifying the problem, preparing good action research, elaborating research procedures, finding relevant studies, and finding expert guidance; (3) difficulties in making the classroom action research report; most of teachers have difficulties in preparing the stages of classroom action research report: writing the background, identifying the problem of the research, engaging with the objectives of the research, collecting relevant studies, getting expert guidance, determining the target achievement of the classroom action research, writing the findings and discussion, drawing conclusions, and finding motivation to write; (4) difficulties in creating popular scientific papers; some teachers complain about the difficulty of identifying ideas/issues, composing good sentences, finding appropriate references, and finding collaborative teacher colleagues, expert guidance, and also motivation; (5) difficulties in writing educational books (including textbooks, translation books, teacher manuals, enriching books, modules/ dictates) most of the teachers have difficulty in terms of finding relevant references, expert guidance, funding, and motivation, as well as in fulfilling their teaching responsibilities and credit report; (6) difficulties in journal writing and publishing book; most of difficulties emphasize that they do not know yet the benefits of publication so they do not have motivation to do it.

Furthermore, in the aspects of innovative work, the difficulties include: (1) difficulties in developing/creating/modifying media and teaching aids and developing visual aids with IT, which is also emphasized on the teaching hours, and the lack of IT skills and also motivation; and (2) difficulties in following the activities of creating instructional guidance/directions, questions, and also standard guidelines at the regency/municipality/province level where most teachers have difficulties with the opportunity to participate in the activities because only some teachers have opportunity to attend the activities.

\section{Document Analysis and Interview Results}

Document analysis using 54 research samples were conducted, while interviews 
were conducted to eight respondents of the research samples. The document analysis was conducted by checking the physical evidence of teacher involvement in each aspect of selfdevelopment activities, scientific publications, and innovation such as scientific works, master degree certificate, certificate of participation in scientific activities (training, seminars, workshops, subject-matter teachers forum (or Musyawarah Guru Mata Pelajaran - MGMP), and/or courses), action research reports, the created/developed/modified mathematical instructional media, and other appropriate physical evidence in the last five years.

The results of the document analysis indicated that in the self-development, some teachers have been improving their education qualifications to master level. Meanwhile, in terms of the certificate of activity, most of teachers have not been involved in MGMP activities in the past two years. Regarding to activity certificates, some respondents are not so much worried about the certificates of their involvement in the activities; they are more concerned with the knowledge in the activities.

In addition, according to the document studies in scientific publications, it is revealed that most of the respondents have followed the activities of writing classroom action research reports, but no document of scientific articles and books was found. Furthermore, in the aspect of innovative work, it was found that most of teachers have created/modified simple instructional media needed for the sub-materials of mathematics learning. Moreover, some respondents followed the activities of creating guidance/directions and mathematics questions sheet at regency/municipality level.

Based on the results of interviews to eight respondents, it is known that the respondents have followed various forms of CPD activities. In fact, most of teachers have been actively involved in regular MGMP activities every month, although some teachers are still less actively involved in the forum. The schedule of the CPD activities which is at the same time of their teaching schedule is one of the difficulties oftenly complained by the teachers.
Another activity followed by the teachers is the national instruction of teaching teachers which is held by the Center of Development and Empowerment of Mathematics Teachers and Personnels (or Pusat Pengembangan dan Pemberdayaan Pendidik dan Tenaga Kependidikan Matematika - P4TK Matematika). It is held based on the result of Teacher's Competence Test (or Uji Kompetensi Guru - UKG) (PPPPTK Matematika, 2016) which end up with some teachers appointed to be national instructors. In addition, some teachers have been actively searching for information on teacher scholarship as well as improving the quality of master degree education qualification with their own funds.

In the aspect of scientific publications, most teachers conduct writing activities based on the action research results which become the prerequisite for obtaining credit numbers promoting their higher level of career. Most of the respondents have understood the action research stages and how they are reported, although they do not know whether their reports are correct or not. In addition, teachers complain about the importance of expert guidance to guide or check their writing. Then, related to the writing activities, some teachers are known to have oftenly written simple works such as arranging action research proposal, but the proposal has not yet completed due to some constraints, namely their teaching schedule, the absence of a guiding expert, the absence of positive support from their working environment, and the motivation to write. Further, related to action research activities, some teachers state the importance of collaborative activities, both in terms of the implementation and reporting.

Furthermore, in creating innovative works, the difficulties that the teachers face in developing teaching media are the lack of motivation and IT skill, their teaching schedule, and and the absence of colleagues to collaborate in carrying out the activities. Meanwhile, the difficulty in following the activity of creating the mathematics instructional guidance and question sheets is that there is no offer and opportunity to follow it. The interview result is presented in Table 6 . 
Table 6. Data analysis of interview results

\begin{tabular}{|c|c|c|}
\hline Aspect & Reduction and Presentation Results & Conclusion (Interpretation) \\
\hline $\begin{array}{l}\text { CPD } \\
\text { Implementation }\end{array}$ & $\begin{array}{l}\text { - Most respondents conduct CPD only in } \\
\text { monthly MGMP activity. } \\
\text { - Some respondents have been, are being, and will } \\
\text { continue to master program either by trying to } \\
\text { find scholarships or with personal funding. } \\
\text { - Some respondents often try to write scientific } \\
\text { paper related to action research but it has not yet } \\
\text { finished. } \\
\text { - There is not found yet a teacher who made } \\
\text { publication papers in the form of popular } \\
\text { scientific writings and books related to } \\
\text { mathematics learning. } \\
\text { - There are respondents who are active to } \\
\text { conduct CPD after the announcement of UKG } \\
\text { results. }\end{array}$ & $\begin{array}{l}\text { The implementation of CPD is still } \\
\text { very less. Most respondents rely on } \\
\text { the activities organized monthly by } \\
\text { the MGMP. Furthermore, in terms } \\
\text { of scientific publication, most } \\
\text { teachers have not started writing } \\
\text { scientific papers, except the action } \\
\text { research result. Meanwhile, in the } \\
\text { innovative works, teachers have } \\
\text { started to create simple innovative } \\
\text { works. The implementation of } \\
\text { teacher's CPD in the aspect of self- } \\
\text { development is better than other } \\
\text { aspects. }\end{array}$ \\
\hline $\begin{array}{l}\text { CPD } \\
\text { Difficulties }\end{array}$ & $\begin{array}{l}\text { - Some respondents are constrained to participate } \\
\text { in self-development activities related to the } \\
\text { teaching schedule, information, and limitations of } \\
\text { the participants. } \\
\text { - Some respondents have difficulty related to the } \\
\text { duration of using computers in writing and } \\
\text { creating IT-based teaching media. } \\
\text { - Most of the respondents have difficulties to } \\
\text { write scientific papers related to action research } \\
\text { because of family responsibilities, as well as the } \\
\text { absence of expert guidance and feedback on the } \\
\text { writing results. } \\
\text { - Some respondents need fellow-teachers to } \\
\text { collaborate with on the creation of scientific } \\
\text { publications and innovative works. }\end{array}$ & $\begin{array}{l}\text { The difficulties that become the } \\
\text { teachers' obstacles related to the } \\
\text { implementation of CPD are as } \\
\text { follows: (1) in the aspects of self- } \\
\text { development: teachers' teaching } \\
\text { schedule, the lack of information on } \\
\text { the CPD activities, and the } \\
\text { establishment of limited participants; } \\
\text { (2) in the aspects of scientific } \\
\text { publications and innovative works: } \\
\text { problems related to the lack of time, } \\
\text { motivation, expert guidance, and } \\
\text { feedback/response of the results of } \\
\text { writing/works. }\end{array}$ \\
\hline
\end{tabular}

\section{Discussion}

Based on the research findings, it is indicated that the implementation of CPD for mathematics teachers in Bandar Lampung is categorized very less in the aspects of selfdevelopment, scientific publications, and innovative works. These findings are supported by the results of document study and interview which make it clear that most teachers are more active in self-development activities than in scientific publications and innovative works. The findings are in accordance with the finding of Wibowo and Jailani (2014, p. 209) that only a few mathematics teachers in have engaged in CPD. Further, based on the details of CPD implementation in each aspect, Kasmayadi (2016, p. ii) states that many mathematics teachers have been involved in CPD activities in the self-development aspect, but they are still poor in the scientific publications and innovative works aspects. Thus, it must be realized that as it is needed by a mathematics teacher, it is important to continuously improve self-competence through self-development activities, scientific publications, and innovative works, which affect the mathematics learning process and the achievement of the learners (Badri, Alnuaimi, Mohaidat, Yang, \& Al Rashedi, 2016, p. 1; Powell, Terrell, Furey, \& Scott-Evans, 2003, p. 389; Ünal et al., 2011, p. 3252).

Another thing to consider about the implementation of scientific publications and innovative works as a part of aspects in CPD is that those aspects require a special assessment team which will follow-up or give feedback to in assessing and reviewing their works, especially related to the results of the action research. Teachers need feedback and review in professional development activities, 
especially in action research, (Chval, Abell, Pareja, Musikul, \& Ritzka, 2008, p. i; Kaur, Bhardwaj, \& Wong, 2017, p. 172) because both feedback and review are important factors to encourage development (New Trier Township High School, 2012, p. 4).

In scientific publication aspect, teachers' CPD activities are dominated by creating classroom action research report because submitting the report is a requirement for gaining credit numbers for the promotion of their level as a civil servant. Meanwhile, other activities such as being a speaker in a seminar/conference are still less conducted. Only some teachers become speakers as in a national instruction program provided by P4TK Mathematics. In addition, there is no teachers found conducting the activities of writing and publishing popular articles, textbooks, modules/ dictates, and translation books.

Furthermore, based on the difficulties faced by mathematics teachers of junior high school in Bandar Lampung, it is known that teachers are categorized in fairly difficult category in the aspects of self-development and scientific publications, and they are in the difficult category in the aspect of innovative work. Based on the difficulties of the CPD implementation in all aspects, it is clear that in self-development aspect, i.e. participation in functional training and collective activities or joining domestic and abroad scholarship programs for teachers, they do not face difficulties related to the support from school principal, especially on functional training and collective activities. This fact is supported by the information obtained from the interviews that all of the interview respondents state that the principals fully support them to conduct CPD, especially in being involved in the monthly MGMP activity. Even, the schools give 0 hour (day off) of teaching on the regular schedule of the MGMP activity. Furthermore, the difficulties to pursue the teachers' higher educational degree to master program are related to their teaching schedule, minimum family support, and funding.

Moreover, the difficulties faced by the teachers face in scientific publications aspect are (1) the difficulty of becoming speakers in scientific forums; some teachers' difficulties are related to the schedule and location of the agenda, and the lack of ideas and motivation; (2) difficulties in conducting action research; some teachers find it is fairly difficult to identify the problem, prepare the action research, arrange the research procedures, find relevant studies, and they find it is very difficult to have experts' guidance; (4) difficulties in writing popular scientific papers; some teachers complain about the difficulty of identifying ideas/issues, composing good sentences, and finding appropriate references, collaborative teacher colleagues, expert guidance, as well as motivation; (5) difficulties in writing educational books (which include textbooks, translation books, enriching books, teacher manuals, modules/dictates); most teachers have difficulty in terms of finding relevant references, expert guidance, fund, motivation, and fulfilling their teaching responsibilities as well as credit report at the same time; and (6) difficulties in writing journal article and publishing book; most of the difficulties emphasize that they do not know the benefits of publication yet so they do not have motivation to do it.

In scientific publication activities, the most common reasons for the difficulty are motivation, expert guidance, and collaboration. Based on the interview results, respondents state that some teachers often join training on scientific works writing, but they are still lack of writing practice. Some of the interview respondents emphasized that they need colleague collaboration and expert guidance to conduct action research and write the report. This result is supported by the important findings that some teachers have not been very proficient or do not know the writing procedures yet, such as how to write popular scientific articles and good textbooks. Further, the respondents hope that there will be such training to improve their skills. This situation is in line with the findings of a research conducted by Kasmayadi (2016, p. 176) which suggests that a certain training, such as functional training, is needed to facilitate CPD and other related topics.

Furthermore, in term of innovative works aspect, the difficulties faced by the teachers include: (1) difficulties in developing/creating/modifying learning media and 
teaching aids with IT, due to their full teaching hours so that they have no opportunities to explore the probability of developing media and kits with or without IT. Some teachers have actually tried to create simple media commonly used in learning mathematics; (2) difficulties in attending the regency/municipality/province/national activity on creating mathematics learning guidance and question sheets; the difficulties are related to the opportunity to participate in such activities because only some teachers can participate in the activities. Furthermore, in relation to the innovative works, most teachers are 'users', they prefer to use the mostly used mathematics materials that have already been available in their working environment. Thus, the main factor is because the limited time and fund (Wibowo \& Jailani, 2014, p. 209).

Teachers' responses in the interview are similar to the finding of a research conducted by Kasmayadi (2016, pp. 175-176) which insists that some teachers state that they have difficulties to implement the CPD. In the selfdevelopment aspect, the reasons are; there is no offer to join the training/course activities, they do not know the way of developing their selves, the have limited time due to their teaching duties or other additional tasks, they do not know the form of the activities (colloquium/panel discussion), and they do not receive the information. In the aspect of scientific publication, the reasons are: there is no offer to become a speaker, they do not have the material and ideas of what to write, they have limited time, and they are not confident to write. Meanwhile, in the innovative work aspect, the reasons of the difficulty of the CPD implementation are their lack of computer skills, limited time, and less motivation as well as idea. Related to the participation in the activities of questions/standards/guidelines preparation, the problem is because the absence of offer to join those activities.

\section{Conclusion and Suggestions}

\section{Conclusion}

Based on the results from CPD checklist sheet, the implementation of CPD activities of junior high school mathematics teach- ers in Bandar Lampung is in very poor category. The majority of teachers are still less involved in the CPD activities either in person or in the forum of subject-matter teachers (MGMP). Furthermore, the aspect of selfdevelopment is categorized fair, very poor, the scientific publication aspect is categorized very poor, and the innovative works aspect is also in very poor category. The difficulties of CPD implementation of JHS mathematics teachers is categorized fair. Furthermore, the difficulties in self-development aspect is categorized fair, in scientific publications aspect is categorized difficult, and in innovative works aspect is categorized very difficult.

The difficulties faced in self-development include: (1) teachers' minimum participation in functional training and collective activities caused by the schedule and location of the activities, the limitation of the participants who can join the activities; and difficulty of pursuing master degree education program because of the lack of information, family permission, and funding; (2) difficulty in conducting action research (publications), especially in identifying the problem, preparing good action research, arranging research procedures, and finding relevant studies and expert guidance. Most teachers have difficulties in creating popular scientific papers, writing journal article, and publishing books. The difficulties face in innovative works aspect include: (1) developing learning media and teaching aids because of teachers' lack of IT skills and motivation; and (2) joining the activities because of limited opportunity to participate in the activities.

Based on document analysis and interview, the implementation of CPD is still very less. Most respondents rely on the activities organized by MGMP monthly. Furthermore, in scientific publication, most teachers have not started writing scientific papers except writing action research report. Meanwhile, in the innovative works, teachers have started to create simple innovative works. The difficulties that become obstacles faced by teachers related to the implementation of CPD include their teaching schedule, the lack of information, and the limitation of participants. In the aspects of scientific publications and innova- 
tive works, the obstacles are related to time, motivation, expert guidance, and feedback from the results of the writing/works.

\section{Suggestions}

Based on the discussion and conclusion of the research, suggestions for the CPD implementation are proposed: (1) for JHS mathematics teachers, it is a must to improve their ability related to classroom action research, paper writing or scientific works, and innovative works. Those activities can give impact on the better learning outcomes of the learners; (2) for school principals, they need to provide support and motivation for teachers to actively engage in various types of CPD activities constantly; (3) for the government, funds are needed to facilitate teachers in their engagement in CPD, especially in joining selfdevelopment training; (4) universities, as educator producers, should add organized coaching programs and equip students with the writing and researching abilities.

\section{References}

Abubakar, A. (2015). Dampak sertifikasi guru terhadap kualitas pendidikan pada Madrasah Aliyah di Kota Kendari. AlQalam, 21(1), 117-128. https://doi.org/ 10.31969/alq.v21i1.204

Aina, M., Bambang, H., Retni, S. B., Afreni, H., \& Sadikin, A. (2015). Pelatihan penulisan karya tulis ilmiah bagi guruguru SMA 8 Kota Jambi. Jurnal Pengabdian Pada Masyarakat, 30(3), 2932.

Alnoor, A. G., \& Yuanxiang, G. (2000). Assessment mathematics teacher's competencies. Wuhan: Central China Normal University.

Badan Standar Nasional Pendidikan. (2015). Aplikasi PAMER UN 2015/2016. Jakarta: BSNP (Badan Standar Nasional Pendidikan).

Badri, M., Alnuaimi, A., Mohaidat, J., Yang, G., \& Al Rashedi, A. (2016). Perception of teachers' professional development needs, impacts, and barriers: The Abu Dhabi case. SAGE Open, 6(3), 1-15. https://doi.org/10.1177/21582440166 62901

Chval, K., Abell, S., Pareja, E., Musikul, K., \& Ritzka, G. (2008). Science and mathematics teachers' experiences, needs, and expectations regarding professional development. Eurasia Journal of Mathematics, Science \& Technology Education, 4(1), 32-43.

Creswell, J. W., \& Clark, V. L. P. (2011). Designing and conducting mixed methods research. Thousand Oaks, CA: SAGE Publications.

Desimone, L. M. (2009). Improving mpact studies of teachers' professional development: Toward better conceptualizations and measures. Educational Researcher, 38(3), 181-199. https://doi.org/10.3102/0013189X083 31140

Fahmi, M., Maulana, A., \& Yusuf, A. A. (2011). Teacher certification in Indonesia: A confusion of means and ends. Working Papers in Economics and Development Studies (WoPEDS). Bandung: Center for Economics and Development Studies (CEDS), Padjadjaran University.

Gray, S. L. (2005). An enquiry into continuing professional development for teachers. Cambridge: Esmee Fairbain Foundation.

Hamilton-Ekeke, J.-T. (2013). Conceptual framework of teachers' competence in relation to students' academic achievement. International Journal of Networks and Systems, 2(3), 15-20.

Jalal, F., Samani, M., Chang, M. C., Stevenson, R., Ragatz, A. B., \& Negara, S. D. (2009). Teacher certification in Indonesia: $A$ strategy for teacher quality improvement. Jakarta: Departemen Pendidikan Nasional Republik Indonesia.

Joubert, M., Back, J., De Geest, E., Hirst, C., \& Sutherland, R. (2010). Professional development for teachers of mathematics: Opportunities and change. In Proceedings of CERME 6 (pp. 1761-1770). Lyon, France: INRP. 
Kardiyem. (2013). Analisis kinerja guru pascasertifikasi (Studi empiris pada guru akuntansi SMK se-Kabupaten Grobogan). Journal of Economic Education, 2(1), 18-23.

Kartowagiran, B. (2011). Kinerja guru profesional (guru pasca sertifikasi). Cakrawala Pendidikan, 30(3), 463-473. https://doi.org/10.21831/cp.v3i3.4208

Kasmayadi, W. (2016). Model asesmen pengembangan keprofesian berkelanjutan guru sekolah menengah atas. Doctoral dissertation. Universitas Negeri Yogyakarta, Yogyakarta.

Kaur, B., Bhardwaj, D., \& Wong, L. F. (2017). Teaching for metacognition project: Construction of knowledge by mathematics teachers working and learning collaboratively in multitier communities of practice. In B. Kaur, O. N. Kwon, \& Y. H. Leong (Eds.), Professional development of mathematics teachers: An Asian perspective (pp. 169187). Boston, MA: Springer.

Law No. 14 Year 2005 of Republic of Indonesia about Teachers and Lecturers (2005).

Layne, H. (2016). Teacher education and teacher's professional development in Finland: Myths and realities. In International Conference on Teacher Education and Professional Development (pp. 8-12). Yogyakarta: LPPMP Yogyakarta State University.

Miles, M. B., Huberman, A. M., \& Saldaña, J. (2014). Qualitative data analysis: $A$ methods sourcebook (3rd ed.). Thousand Oaks, CA: Sage.

Ministry of National Education of Republic of Indonesia. (2010). Pembinaan dan pengembangan profesi guru buku I: Pedoman pengelolaan keprofesian berkelanjutan (PKB) dan angka kereditnya. Jakarta: Direktorat Jenderal Peningkatan Mutu dan Tenaga Kependidikan.

New Trier Township High School. (2012). Characteristic of professional practice at New Trier High School. Northfield, IL: New
Trier Township High School District 203.

Noorjannah, L. (2015). Pengembangan profesionalisme guru melalui penulisan karya tulis ilmiah bagi guru profesional di SMA Negeri 1 Kauman Kabupaten Tulungagung. Jurnal Humanity, 10(1), 97-114.

Nuraeni, Z., \& Retnawati, H. (2016). The post-certification performance of mathematics teachers. The Online Journal of New Horizons in Education, 6(2), 130 142.

Opfer, V. D., \& Pedder, D. (2010). Benefits, status and effectiveness of Continuous Professional Development for teachers in England. The Curriculum Journal, 21(4), 413-431. https://doi.org/10.1080/095 85176.2010 .529651

Powell, E., Terrell, I., Furey, S., \& ScottEvans, A. (2003). Teachers' perceptions of the impact of CPD: An institutional case study ed. Journal of In-Service Education, 29(3), 389-404. https://doi. org/10.1080/13674580300200282

PPPPTK Matematika. (2016). Hasil UKG 2015. Unpublished. PPPPTK Matematika, Yogyakarta.

Qablan, A., Mansour, N., Alshamrani, S., \& Aldahmash, A. (2015). Ensuring effective impact of continuing professional development: Saudi science teachers' perspective. Eurasia Journal of Mathematics, Science and Technology Education, 11(3), 619-631. https://doi.org/10.12973/eurasia.2015. $1352 \mathrm{a}$

Regulation of the Minister for the State Apparatus Empowerment and Bureaucracy Reform No. 16 of 2009 on Teachers' Functional Position and Their Credit Points (2009). Republic of Indonesia.

Regulation of the Minister of Education and Culture No. 20 of 2016 on the competence standard of primary and secondary education graduates (2016). Republic of Indonesia. 
Regulation of the Minister of National Education No. 19 of 2005, on National Education Standard (2005). Republic of Indonesia.

Supriyanto, A. (2015). Harapan, kenyataan dan strategi peningkatan kemampuan guru dalam penulisan karya tulis ilmiah. In Prosiding Seminar Nasional Pengembangan Keprofesian Menuju Guru Profesional (pp. 109-114). Malang: Universitas Negeri Malang.

Tuijnman, A., \& Boström, A.-K. (2002). Changing notions of lifelong education and lifelong learning. International Review of Education, 48(1/2), 93-110.

Ünal, H., Demir, I., \& Kiliç, S. (2011). Teachers' professional development and students' mathematics performance: Findings from TIMSS 2007. Procedia - Social and Behavioral Sciences, 15, 3252-3257. https://doi.org/10.1016/j.s bspro.2011.04.280

UNESCO. (2014). Education strategy 20142021. Paris: UNESCO.

UNICEF. (2007). A buman rights-based approach to education for all. New York, NY: United Nations Educational, Scientific, and Cultural Organization.
Wermke, W. (2011). Continuing professional development in context: Teachers' continuing professional development culture in Germany and Sweden. Professional Development in Education, 37(5), 665-683. https://doi.org/10.10 $80 / 19415257.2010 .533573$

Wibowo, E., \& Jailani, J. (2014). Analisis kesulitan guru matematika SMP dalam pengembangan profesi di Kabupaten Wonosobo. Jurnal Riset Pendidikan Matematika, 1(2), 202-215. https://doi. org/10.21831/jrpm.v1i2.2676

Widoyoko, E. P. (2013). Evaluasi program pembelajaran: Panduan praktis bagi pendidik dan calon pendidik. Yogyakarta: Pustaka Pelajar.

World Bank. (2010). Transforming Indonesia's teaching force. Washington, DC: Human Development East Asia and Pacific Region, World Bank.

Yacoub, Y. (2012). Pengaruh tingkat pengangguran terhadap tingkat kemiskinan Kabupaten/Kota di Provinsi Kalimantan Barat. Jurnal EKSOS, 8, 176-185. 